\title{
Changes in temperature and temperature gradients in the French Northern Alps during the last century
}

\author{
Dominique Dumas dominique.dumas@univ.lyon3.fr
}

\begin{abstract}
In moutain environments, local factors such as topography or exposure to the sun influence the spatial distribution of temperatures. It is therefore difficult to characterise the global evolution of temperatures over several decades. Such local effects can either accentuate or attenuate thermal contrasts between neighbouring areas. The present study uses two regional thermal indicators thermal gradients and temperatures reduced to sealevel - to monitor the monthly evolution of minimum and maximum temperatures in the French Northern Alps. Measures were calculated for the period extending from 1960 to 2007 based on data from 92 measuring stations. Temperature gradients were computed and further used to monitor the altitudinal evolution of temperatures. A
\end{abstract}

characteristic regional temperature was determined for the whole of the French Northern Alps based on temperatures reduced to sea-level, and changes in temperatures since 1960 were assessed. Multiple linear regression models made it possible to extend measurements over a longer period, and to make enhanced calculations of temperature changes in the mountains since 1885. This is the first study to examine temperature changes in the French Northern Alps over such an extended period. Gradient data suggest that over the last 50 years temperatures have changed at all altitudes. In addition, the evaluation of the temperature rise over 100 years reveals that minimal and maximal monthly temperatures trends are only significant a few months of the year.

Key words: Alps, climate change, temperature, gradient, trends, statistical significance

\section{INTRODUCTION}

Interpreting temperatures in mountainous areas has never been straightforward. Previous studies of temperature have illustrated the complex relationship between temperature and relief (Angot, 1892; Harding, 1978; Douguedroit and Saintignon, 1984; Bücher and Dessens, 1991; Beniston et al., 1994; Beniston et al., 1997; Weber et al., 1997; Diaz and Bradley, 1997; Böhm et al., 2001; Rolland, 2003; Beniston, 2006; Barry, 2008). Local factors, such as topography, can interfere with the overall interpretations made at regional scales. For instance, valleys in close relation to one another might show very different intra- or inter-annual climate evolutions. In addition, a number of factors can come into play to modulate the temperatures measured by weather stations in mountain areas: altitude, orientation, valley shape, and location (Diaz and Bradley, 1997; Weber et al., 1997). Altitude is nevertheless the most influential of these parameters, as montly and yearly temperatures are closely related to altitude.

There has been a great amount of scientific research into environmental changes in the Alps, mostly using either proxy data or data obtained from sites equipped with measuring devices (examples include the annual mass balance of a number of glaciers, modifications in Alpine vegetation, dendrochronological studies, monitoring of the snow mantle, modifications in hydrological and hydrosedimentary flows, etc.). This often obliges one to link observed environmental changes with the evolution of temperatures on a regional scale. The aim of the present study was to provide data enabling one to relate the observed environmental changes and the evolution of temperature at a regional scale. Such data should prove particularly useful to understand the environmental changes at the scale of the 
French Northern Alps since the late $19^{\text {th }}$ century.

Based on the measures of temperatures of nearly one hundred stations of known altitudes, it has been possible to make an accurate assessment of the inter-annual temperature evolutions for the entire area of the French Northern Alps (Figure 1). Temperature changes between 1960 and 2007 will be described first, based on two regional monthly indicators, thermal gradient and temperature reduced to sealevel (Dumas and Antunes, 2003; Dumas and Rome, 2009). The calculation of reduced temperatures enabled us to follow the temporal evolution of temperatures over the entire French Northern Alps region, while the calculation of thermal gradients revealed the relation between temperature and altitude. The evolution of temperature variations related to altitude will thus be described with monthly and annual temperature gradients for a period of almost 50 years. Second, monthly values of reduced temperatures were extrapolated over the period extending from 1885 to 2007. The evolution of maximum and minimum regional temperatures can therefore be described for a period of over 120 years.

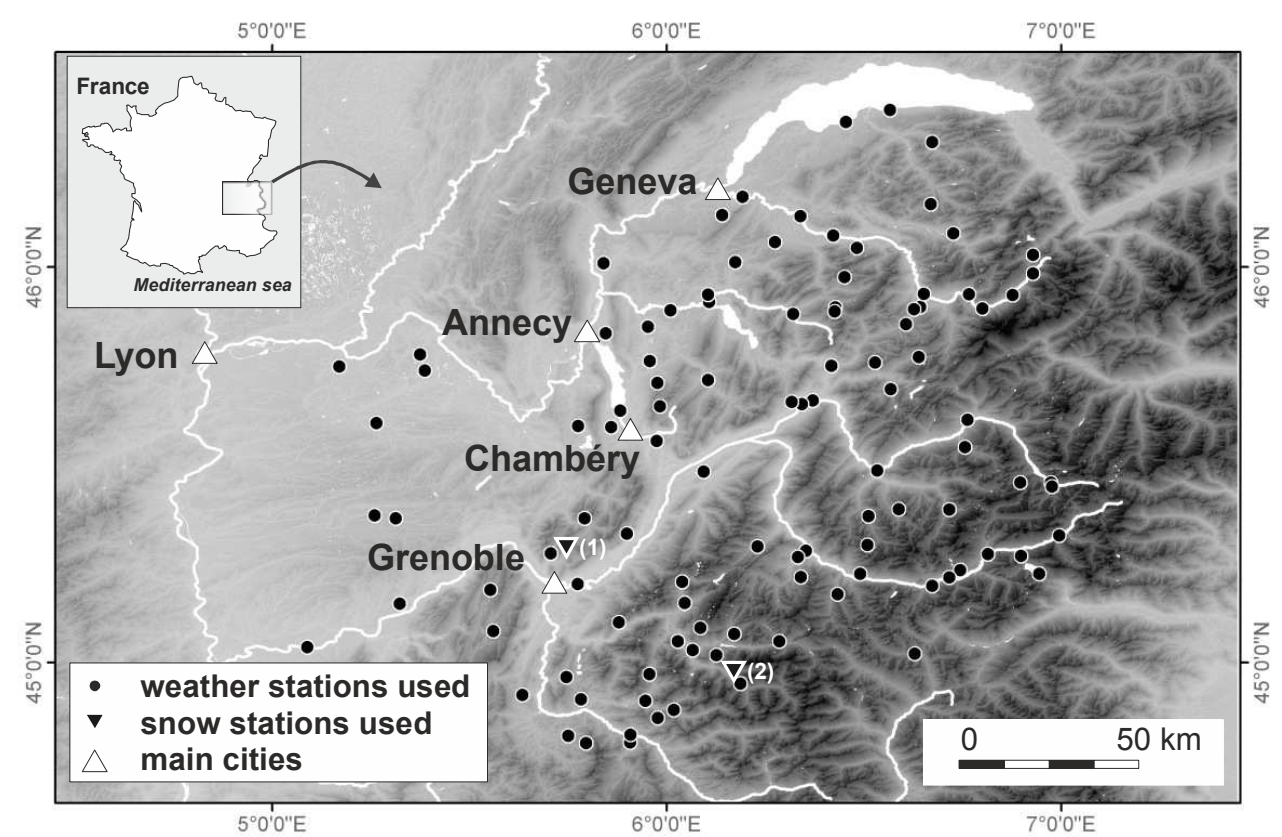

Figure 1. The location of the 92 MétéoFrance weather stations used in the present study (snow stations ; 1 - Col de Porte, 2 - Saint Christophe)

\section{DATA AND METHODS}

The study was carried out in the French Northern Alps using meteorological data gathered in the French departments of Isère, Savoie, Haute-Savoie and HautesAlpes. This area does not cover all of the French Alps, but the aim was to work on a rather homogenous climate zone (Douguedroit and Saintignon, 1984; Dumas and Antunes, 2003; Beniston, 2006; Dumas and Rome, 2009). The area is large enough to include a variety of topographical features: valley floors, slopes and summits.

The first step was to identify over 150 MétéoFrance (the French Meteorological Agency) stations in the study area. Mean monthly temperatures were computed from daily minimum, maximum and average temperatures. Data from a few stations were set aside for the following reasons: deviations in the records, measurement periods of less than eight years, or 
excessively long gaps in the records. A total of 92 stations were selected for the period between 1960 and 2007. The stations selected were ordered according to their altitude, exposure and topographical features. Altitudes ranged from $134 \mathrm{~m}$ (Sablons) to $2800 \mathrm{~m}$ (St-Martin-deBelleville), although $95 \%$ of the stations were below $2000 \mathrm{~m}$, and $15 \%$ were between $1500 \mathrm{~m}$ and $2000 \mathrm{~m}$.

Gaps were filled in on the monthly data so as to build up monthly indicators with a homogenous data set. The homogeneity of series was verified in monthly steps using the method of cumulative residuals (Bois, 1971; Buishand, 1984; Hubert et al., 1989). The detection of possible deviations was improved beforehand by deseasonalising temperatures (Ladiray and Quenneville, 2001). In order to carry this out, data were standardised (i.e. centred with the mean and then reduced using the standard deviation of monthly values). This enabled the heterogeneity of several series to be detected and corrected. It should be noted that the impact of such corrections on the final results was quite limited as on one hand the most heterogeneous series were left out of the study, while on the other hand the large number of measurement points greatly limited the possible influence of untypical stations on the results.

\subsection{Calculating two regional indicators}

For the period extending from 1960 to 2007, based on linear models monthly means of the minimum (Tn), maximum (Tx) and mean (Tg) daily temperatures were used to calculate a temperature reduced to sea level, as well as a gradient of the fall in temperature (Figure 2). These monthly estimations, calculated on the basis of the altitude of the stations, could have been refined by also taking topographical variations into account. For example, including such topographical data in a multiple linear regression model would have yielded a lower residual variance. However, a study dissociating sites from their topographical features would not have given an overall view of climate changes in the French Northern Alps on the basis of only two parameters.

In addition, the two indicators stemming from a linear regression remain relevant provided that the relationship be verified and validated by statistical tests. In the present study, the linear regression models between weather-station altitudes and their mean monthly temperatures were systematically verified using four tests: Bravais-Pearson, Fisher-Snedecor, Student tests on origin and slope. The significance level was set at $1 \%$.

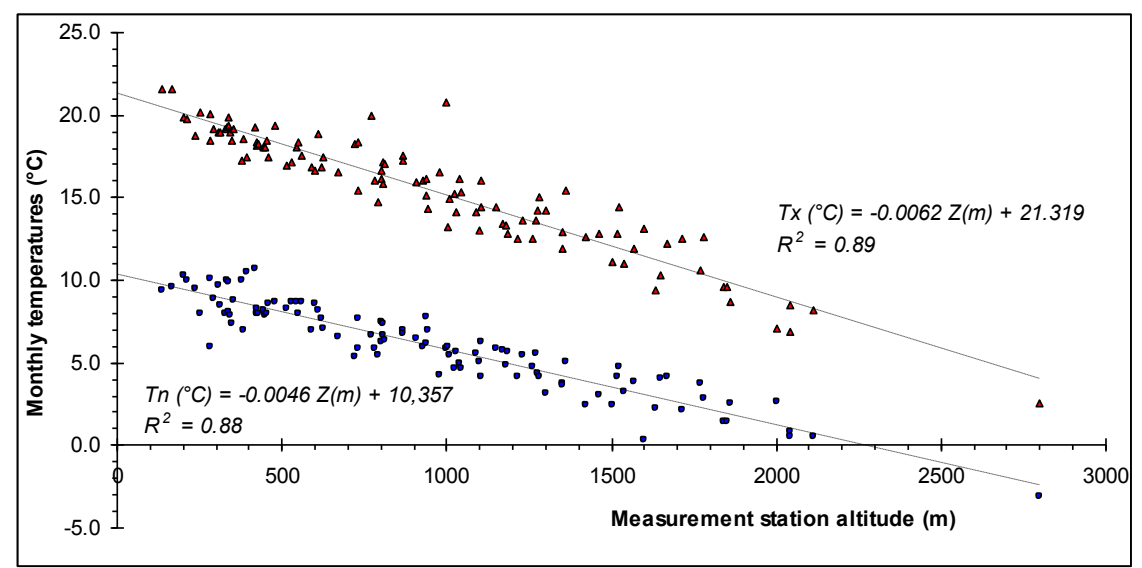

Figure 2. The correlation of Tn and Tx temperatures as a function of the altitude of measurement stations. An example of monthly temperatures in September 2001: - for Tx: gradient $=0.62^{\circ} \mathrm{C} .100 \mathrm{~m}^{-1}$, regional temperature $=21.3^{\circ} \mathrm{C}$ - for Tn: gradient $=0.46^{\circ} \mathrm{C} .100 \mathrm{~m}^{-1}$, regional temperature $=10.4^{\circ} \mathrm{C}$ 


\subsection{Reconstructing monthly mean temperatures from 1885 to 2007}

The period from 1885 to 2007 was chosen to define the climate changes having taken place in the French Northern Alps. The reconstruction relies on the data from three stations whose observations cover the whole of the 20th century, and whose observational conditions have remained completely or largely unchanged. Data from two of the stations, Annecy (elevation: 458m) and Lyon (elevation: 207m), were taken from the MétéoFrance data bank, and that of the third, Geneva (elevation: $420 \mathrm{~m}$ ), from the Météo Suisse data bank. The three series had already been homogenised using algorithms belonging to MétéoFrance (Mestre, 2000; Caussinus and Mestre, 2004) and Météo Suisse (in the "Data Warehouse" database). These three stations were left out of the calculations of gradients and reduced temperatures beforehand so as not to introduce any bias or establish regression models from non-independent variables. It was thus possible to not only study the temperature changes in the French
Northern Alps since the 1960s, but also over a longer period by reconstructing temperatures. Such reconstitutions cannot, however, be carried out with the same robustness for the temperature gradients. This would have requires a large number of observations from stations spanning a wide range of altitudes. Data spanning the 120 years' period were only available for the three stations of Annecy, Lyon and Geneva, spanning an elevation range of $250 \mathrm{~m}$ only, as compared to 92 stations distributed over a maximum elevation range of $2500 \mathrm{~m}$.

To reconstruct the temperatures since 1885, we used a validation procedure based on observations that were fully independent on the models. The first step consisted in dividing the 92 stations into two comparable and homogeneous groups. The stations were ordered based on their altitude, and every other station was then allotted to one group while the other half was allotted to the other group. Figure 3 illustrates the actual altitudinal distribution of the stations of the two groups for the maximal temperature of June 1960.

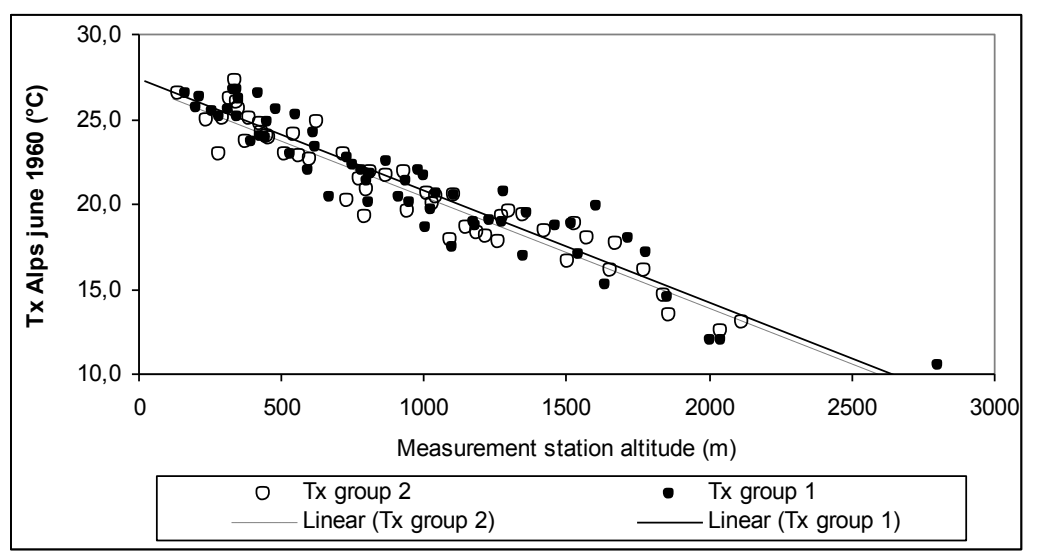

Figure 3. Distribution of the stations in two groups: example based on June 1960 maximal temperatures.

The first group of stations was used as the training group. Multiple linear regressions were computed monthly over the 1960 2007 period with the data collected from the three stations providing information from 1885 to 2007. Annual values were then calculated from mean monthly values.

Regional minimum and maximum temperatures calculated monthly from 
1960 to 2007 are always strongly correlated with the three observation series (Table 1; Figures 4 and 54). The monthly correlation coefficients between regional temperatures and temperatures from the Annecy, Lyon and Geneva stations always exceed 0.93 ; at least $86 \%$ of the variance of the regional temperatures can therefore be explained by the series of temperatures used in the regression models (Table 1). In addition to the Bravais-Pearson test, the linear regression models were validated using the Fischer-Snedecor test with a level of significance set below $1 \%$ (significant at $\mathrm{p}<0.01$ ).

Table 1. Monthly values of the correlation coefficient $\mathrm{R}$ and the $\mathrm{F}$ ratio (Fischer-Snedecor test) for minimum, maximum and average monthly temperatures ( $\mathrm{Tn}$, $\mathrm{Tx}$ and $\mathrm{Tg}$ )

\begin{tabular}{|c|c|c|c|c|c|c|}
\hline \multirow[b]{2}{*}{ Month } & \multicolumn{2}{|c|}{$\mathrm{Tg}$} & \multicolumn{2}{|c|}{ Tn } & \multicolumn{2}{|c|}{$T x$} \\
\hline & $\mathbf{R}$ & $\mathrm{F}$ & $\mathbf{R}$ & F & $\mathbf{R}$ & $\mathbf{F}$ \\
\hline 1 & 0,975 & 278,7 & 0,956 & 154,3 & 0,977 & 308,3 \\
\hline 2 & 0,979 & 342,3 & 0,966 & 202,9 & 0,979 & 346,5 \\
\hline 3 & 0,987 & 545,1 & 0,965 & 198,6 & 0,985 & 485,9 \\
\hline 4 & 0,981 & 376,0 & 0,927 & 89,4 & 0,984 & 458,1 \\
\hline 5 & 0,982 & 406,0 & 0,947 & 125,8 & 0,985 & 473,1 \\
\hline 6 & 0,982 & 392,8 & 0,965 & 199,5 & 0,984 & 443,9 \\
\hline 7 & 0,969 & 220,1 & 0,948 & 130,9 & 0,963 & 190,1 \\
\hline 8 & 0,969 & 222,8 & 0,948 & 129,9 & 0,960 & 173,2 \\
\hline 9 & 0,988 & 591,6 & 0,968 & 217,0 & 0,984 & 455,6 \\
\hline 10 & 0,985 & 476,1 & 0,978 & 316,2 & 0,981 & 368,2 \\
\hline 11 & 0,968 & 216,7 & 0,952 & 142,1 & 0,970 & 228,1 \\
\hline 12 & 0,973 & 264,4 & 0,967 & 224,4 & 0,962 & 180,0 \\
\hline
\end{tabular}

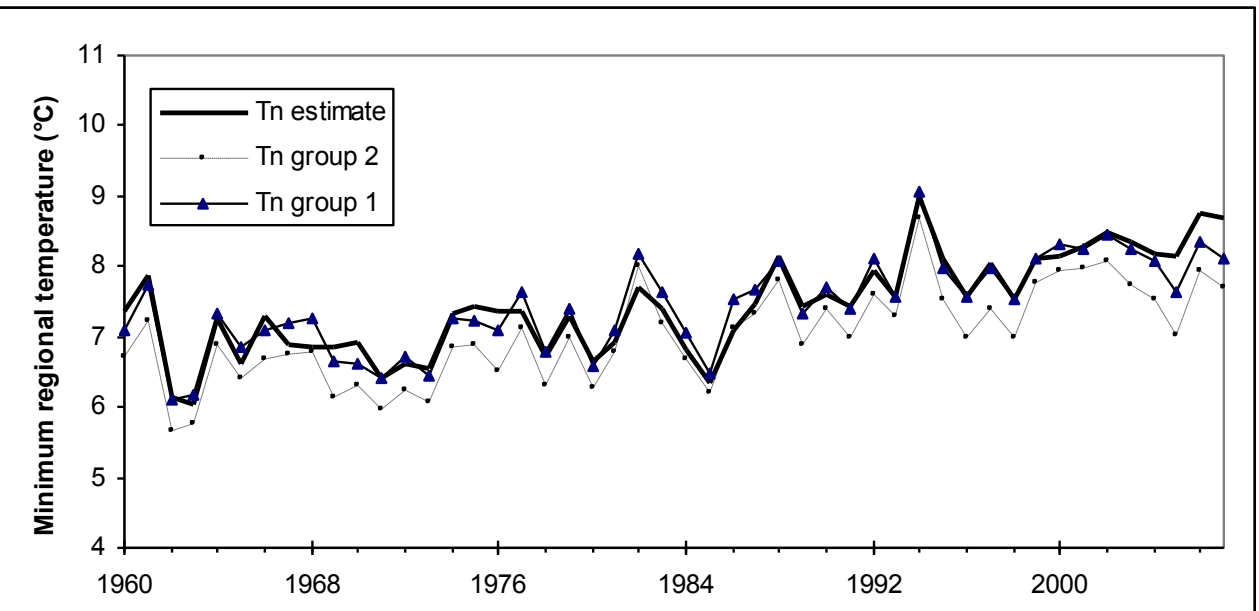

Figure 4. The time series of minimum annual temperatures in the northern Alps (Tn Alps) calculated and reconstructed for 1960-2007.

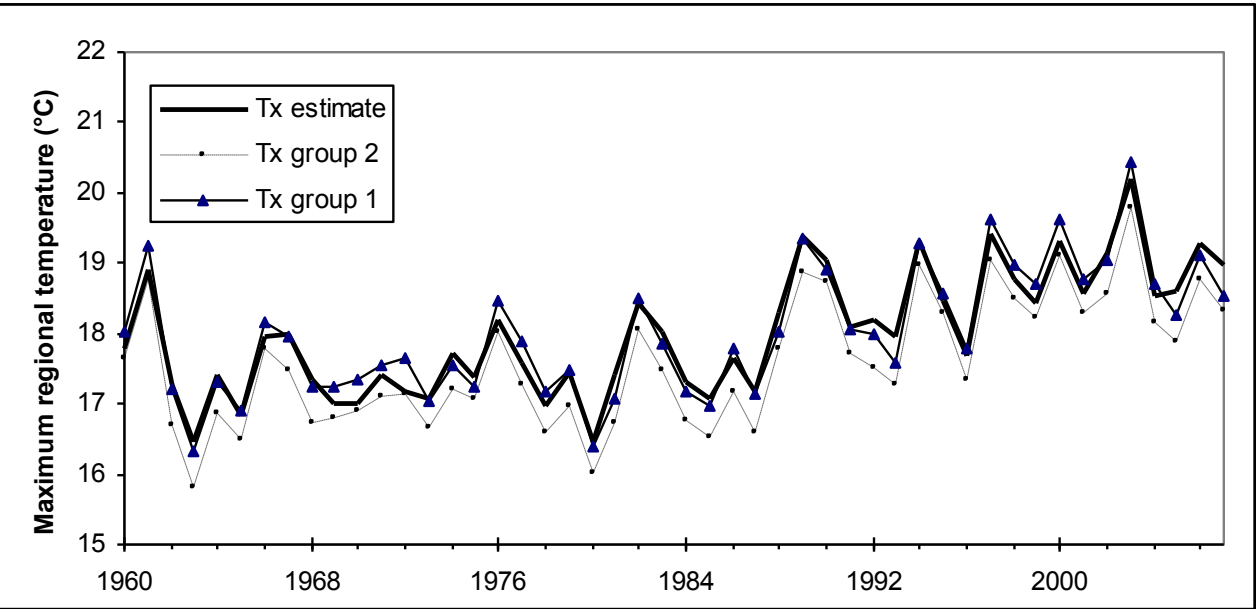

Figure 5. The time series of maximum annual temperatures in the northern Alps (Tx Alps) calculated and reconstructed for 1960-2007. 
The monthly models were then tested on the set of independent data from the test group. As shown on Figure 6 for the minimal July temperatures, the values estimated by the model were also strongly correlated with the observations of the test group. This held true for the whole set of data, as can be seen on Table 2 .

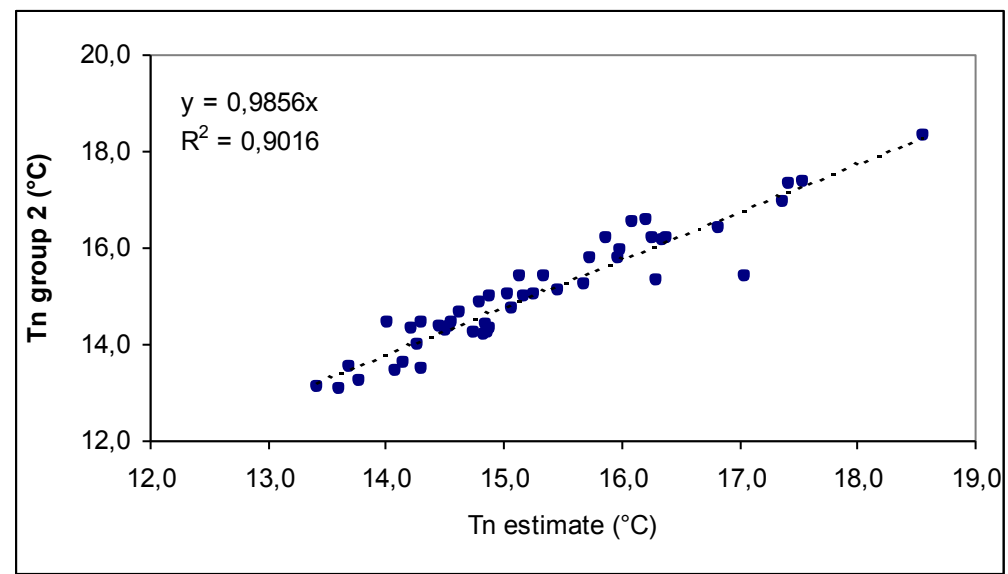

Figure 6. Example of the mean minimal July temperatures. Relation between the computed and observed monthly temperatures for the 1960-2007 period.

Table 2. Correlation coefficients (R) and values of the Fisher-Snedecor test (F) for the monthly computed and observed temperatures of the test group over the 1960-2007 period.

\begin{tabular}{ccc} 
& \multicolumn{2}{c}{ Tn } \\
\cline { 2 - 3 } Month & $\mathrm{R}$ & $\mathrm{F}$ \\
\hline 1 & 0,956 & 0,611 \\
2 & 0,977 & 0,553 \\
3 & 0,962 & 0,869 \\
4 & 0,915 & 0,626 \\
5 & 0,935 & 0,555 \\
6 & 0,955 & 0,912 \\
7 & 0,940 & 0,819 \\
8 & 0,931 & 0,982 \\
9 & 0,949 & 0,815 \\
10 & 0,964 & 0,913 \\
11 & 0,950 & 0,661 \\
12 & 0,967 & 0,526
\end{tabular}

\begin{tabular}{cc}
\multicolumn{3}{c}{$T \boldsymbol{X}$} \\
\hline $\mathrm{R}$ & $\mathrm{F}$ \\
\hline 0,978 & 0,536 \\
0,990 & 0,423 \\
0,993 & 0,258 \\
0,991 & 0,245 \\
0,988 & 0,648 \\
0,987 & 0,548 \\
0,980 & 0,538 \\
0,978 & 0,966 \\
0,986 & 0,289 \\
0,979 & 0,701 \\
0,970 & 0,287 \\
0,975 & 0,899
\end{tabular}

\begin{tabular}{cc}
\multicolumn{2}{c}{ Tg } \\
\hline $\mathrm{R}$ & $\mathrm{F}$ \\
\hline 0,979 & 0,589 \\
0,989 & 0,609 \\
0,993 & 0,990 \\
0,983 & 0,952 \\
0,985 & 0,906 \\
0,989 & 0,876 \\
0,980 & 0,819 \\
0,983 & 0,838 \\
0,984 & 0,885 \\
0,985 & 0,868 \\
0,976 & 0,753 \\
0,982 & 0,597
\end{tabular}

Thus, the validation procedure revealed highly significant correlations between the calculated and observed values in the test group, confirming the robustness of the procedure. Therefore, it was possible to reliably extend and extrapolate the temperatures' series to the 1885-2007 period.

\subsection{Estimating trends}

Inter-annual evolution and warming rates throughout the French Northern Alps can be examined over 48 years for gradients and 123 years for temperatures. The total change based on the mean trend during the observation period (1960-2007 or 18852007) was obtained by multiplying the slope of the regression line by 100 .

The trend analysis was performed using a linear regression analysis and MannKendall test. The Mann-Kendall test (MK), a non-parametric test for trend detection in a time series, has been widely used in environmental sciences (Mann, 1945; Kendall, 1975; Sneyers, 1975; Vialar, 1978; Kundzewicz et Robson, 2000; Böhm et al., 2001). The comparison of several 
tests applied to hydrological and climate series has frequently shown MK's value and strength (Hirsch et al., 1984; Gerstengarbe and Werner, 1999; Yue et al., 2002; Kundzewicz et al., 2005). MK generally turns out to be more robust than Student or Spearman tests, as it is less affected by abnormal values. Nonparametric $\mathrm{MK}$ can be used to detect monotonic trends that are not necessarily linear. The null hypothesis in $\mathrm{MK}$ is that the data are independent and randomly ordered. In the present study, trends are considered to be statistically significant at $\mathrm{p}<0.05$, and highly significant at $\mathrm{p}<0.01$.

\section{RESULTS}

\subsection{Intra-seasonal and inter-annual gradient evolution}
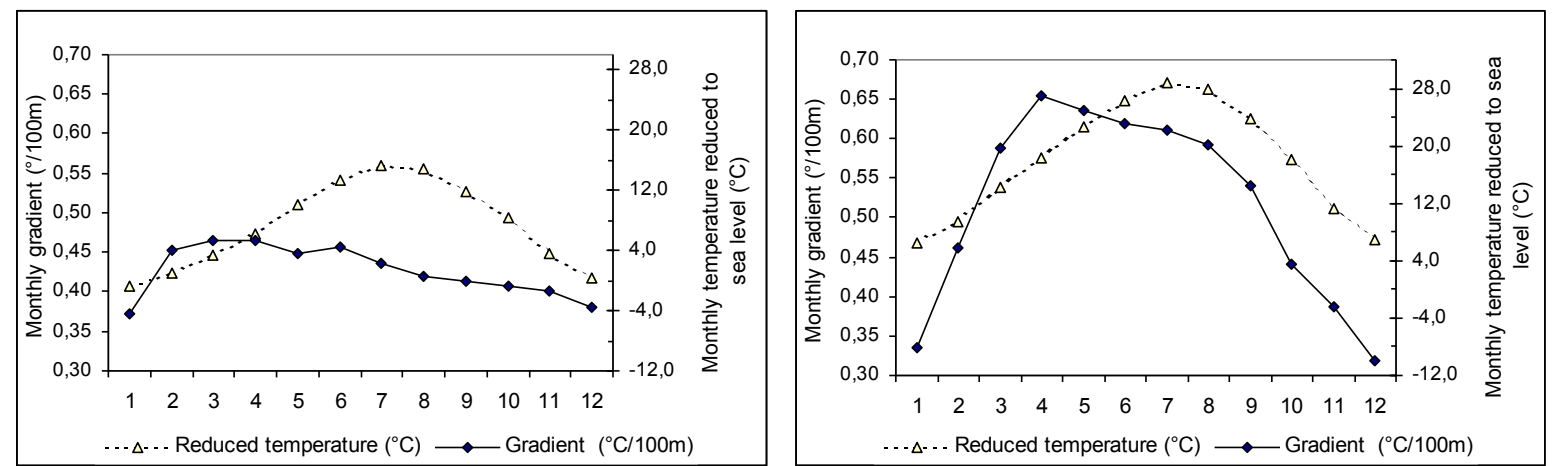

Figure 7. The mean monthly evolution of gradients and regional temperatures in the northern Alps: Tn is on the left, Tx on the right.

Table 3. Monthly gradients (in ${ }^{\circ} \mathrm{C} / 100 \mathrm{~m}$ ) of minimum (Tn) and maximum (Tx) temperatures. Extreme values, standard deviations and trends for the period from 1960 to 2007

\begin{tabular}{|c|c|c|c|c|c|c|c|c|c|c|c|c|c|c|c|}
\hline & \multicolumn{3}{|c|}{ Mean 1960-2007 } & \multicolumn{6}{|c|}{ Tn $1960-2007$} & \multicolumn{6}{|c|}{ Tx $1960-2007$} \\
\hline & $\mathrm{Tg}$ & Tn & Tx & $\min$ & $\max$ & $\sigma$ & $\begin{array}{c}\text { Trend }{ }^{\circ} \mathrm{C} / 100 \mathrm{~m} \\
\text { per } 10 \text { years }\end{array}$ & $\mathrm{u}(\mathrm{t})$ & MK & $\min$ & $\max$ & $\sigma$ & $\begin{array}{c}\text { Trend }{ }^{\circ} \mathrm{C} / 100 \mathrm{~m} \\
\text { per } 10 \text { years }\end{array}$ & $\mathrm{u}(\mathrm{t})$ & MK \\
\hline January & 0,35 & 0,37 & 0,34 & 0,18 & 0,55 & 0,08 & 0,012 & 1,53 & $\phi$ & $-0,06$ & 0,50 & 0,11 & 0,009 & 0,62 & $\phi$ \\
\hline February & 0,46 & 0,45 & 0,46 & 0,19 & 0,66 & 0,08 & 0,005 & 1,01 & $\phi$ & 0,27 & 0,62 & 0,09 & 0,005 & 0,57 & $\phi$ \\
\hline March & 0,53 & 0,46 & 0,59 & 0,35 & 0,58 & 0,05 & 0,000 & 0,30 & $\phi$ & 0,46 & 0,68 & 0,05 & 0,012 & 2,03 & $*$ \\
\hline April & 0,56 & 0,47 & 0,66 & 0,35 & 0,54 & 0,04 & $-0,003$ & $-0,12$ & $\phi$ & 0,55 & 0,73 & 0,04 & 0,011 & 2,20 & $*$ \\
\hline May & 0,54 & 0,45 & 0,64 & 0,39 & 0,50 & 0,02 & 0,000 & $-0,34$ & $\phi$ & 0,57 & 0,72 & 0,04 & 0,002 & 0,60 & $\phi$ \\
\hline June & 0,54 & 0,46 & 0,62 & 0,38 & 0,54 & 0,03 & $-0,002$ & $-0,39$ & $\phi$ & 0,46 & 0,77 & 0,04 & $-0,006$ & $-1,33$ & $\phi$ \\
\hline July & 0,52 & 0,44 & 0,61 & 0,37 & 0,53 & 0,03 & 0,000 & 0,94 & $\phi$ & 0,47 & 0,73 & 0,05 & $-0,011$ & $-1,69$ & $\phi$ \\
\hline August & 0,51 & 0,42 & 0,59 & 0,31 & 0,50 & 0,04 & $-0,001$ & $-0,07$ & $\phi$ & 0,43 & 0,73 & 0,05 & $-0,005$ & $-1,23$ & $\phi$ \\
\hline September & 0,48 & 0,41 & 0,54 & 0,32 & 0,51 & 0,04 & 0,000 & 0,07 & $\phi$ & 0,45 & 0,62 & 0,04 & 0,002 & 0,57 & $\phi$ \\
\hline October & 0,42 & 0,41 & 0,44 & 0,30 & 0,51 & 0,05 & $-0,002$ & $-0,43$ & $\phi$ & 0,33 & 0,59 & 0,06 & 0,002 & 0,68 & $\phi$ \\
\hline November & 0,39 & 0,40 & 0,39 & 0,27 & 0,50 & 0,06 & $-0,013$ & $-2,06$ & * & 0,20 & 0,55 & 0,09 & $-0,007$ & $-0,82$ & $\phi$ \\
\hline December & 0,35 & 0,38 & 0,32 & 0,22 & 0,55 & 0,07 & 0,004 & 0,07 & $\phi$ & 0,14 & 0,53 & 0,09 & 0,005 & 0,52 & $\phi$ \\
\hline Min & 0,35 & 0,37 & 0,32 & 0,18 & 0,50 & 0,02 & $-0,013$ & & & $-0,06$ & 0,50 & 0,04 & $-0,011$ & & \\
\hline Max & 0,56 & 0,47 & 0,66 & 0,39 & 0,66 & 0,08 & 0,012 & & & 0,57 & 0,77 & 0,11 & 0,012 & & \\
\hline Annual & 0,47 & 0,43 & 0,52 & 0,36 & 0,47 & 0,02 & 0,000 & $-0,05$ & $\phi$ & 0,44 & 0,58 & 0,03 & 0,015 & 0,78 & $\phi$ \\
\hline
\end{tabular}

Significance levels of the Mann-Kendall test (MK): ** is $0.01 ; *$ is $0.05 ; \phi>0.05$
The seasonal evolution obtained from the 1960-2007 monthly values revealed an annual dynamics. Such a dynamic had not yet been fully described for the Alps (Figure 7). Based on reduced temperature, the mean annual temperature amplitude in this area can be estimated as $16.0^{\circ} \mathrm{C}$ for the minima, and $22.3^{\circ} \mathrm{C}$ for the maxima. The mean annual temperature is estimated as $7.3^{\circ} \mathrm{C}$ for the minima and $17.8^{\circ} \mathrm{C}$ for the maxima. Although the mean annual gradients (Table 3) are $0.43^{\circ} \mathrm{C}$ per $100 \mathrm{~m}$ for $\mathrm{Tn}$, and $0.52^{\circ} \mathrm{C}$ per $100 \mathrm{~m}$ for $\mathrm{Tx}$, seasonal variations are clearly noticeable. The gradients show an annual cycle which can also be found in other mountain regions (Harding, 1978). The cycle observed in the Alps is slightly out of step with respect to the seasonal evolution of temperatures, with a fairly rapid rise early in the year, followed by a slower drop towards the end of the year (Figure 7). 
Mean monthly gradients are shown on Table 3. They fluctuate between 0.37 and $0.47^{\circ} \mathrm{C}$ per $100 \mathrm{~m}$ for $\mathrm{Tn}$, and between 0.32 and $0.66^{\circ} \mathrm{C}$ per $100 \mathrm{~m}$ for Tx. The gradients' evolution remains progressive and regular. Regarding the minimum and maximum temperatures, the smaller gradients are observed in DecemberJanuary, and the greatest in April. Such seasonality has not always been described in the Alps, some authors reporting more complex, if not random, monthly variations of the gradients (Angot, 1892; Saintignon, 1976; Dougédroit and Saintignon, 1981; Bisci et al., 1989). However, other studies found similar trends, with lower gradients in winter and higher ones in summer (Harding, 1978; Rolland, 2003; Barry, 2008). This type of seasonal cycle can partly be explained by more frequent thermal inversions in the cold season and by the particularly unstable nature of the atmosphere in spring, favouring a more active vertical mingling. However, it is also a consequence of the radiative and turbulent heat exchanges which progressively change over the year with the path of the sun and the multiple interactions of radiations with the relief. However, there does not seem to be a direct link with the presence of a snow cover, suggested in some studies of thermal gradients (Douguédroit and Saintignon, 1981; Bisci et al., 1989; Rolland, 2003) (Figure 8). As can be seen, the greatest gradients, in April, are not related to the specific state of the snow cover, and their decrease continues smoothly after the snow has melted in May, or somewhat later at greater altitudes.
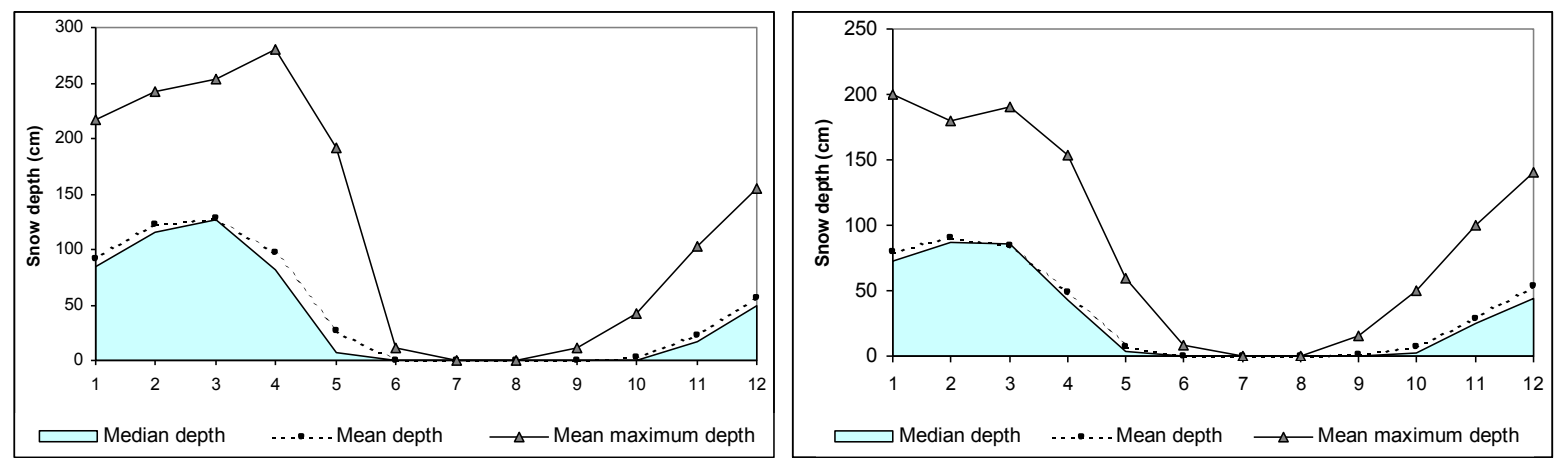

Figure 8. Mean monthly evolution of the snow cover computed over the period 1961-2010 from the daily data at the Col de Porte (1325 m: data Météo-France, CNRS, CNRM-GAME, CEN) on the left, and Saint Christophe (1570 m: data Météo-France) stations.

Although their seasonal evolutions are similar, maximum temperature gradients are greater than minimum gradients throughout the year, except for the months of January and December. Minima are more frequently linked to higher relative humidity, which tends to attenuate the decrease of temperatures with altitude. For instance, in adiabatic conditions at ground level, the humid adiabatic gradient at a temperature of $15^{\circ} \mathrm{C}$ is around $0.5^{\circ} \mathrm{C}$ per $100 \mathrm{~m}$, whereas the dry adiabatic gradient is close to $1.0^{\circ} \mathrm{C}$ per $100 \mathrm{~m}$ (Barry and Chorley, 1998; Triplet and Roche, 2000).
On an inter-annual scale, scarcely studied in the literature and never in the French Northern Alps, mean monthly and yearly gradients all exhibit a high degree of variability. Depending on the year and month, monthly temperature gradients can vary by ratios of 1 to more than 3 , and even 1 to 9 for maximum temperature gradients in January. Monthly standard deviations (Table 3) are greater in autumn and winter (from October to February), reflecting the gradients' greater interannual variability linked to more frequent thermal inversions in the valleys. Such 
inversions are influenced by a number of climatic parameters such as cloud cover, wind speed and direction, and air temperature.

Overall, monthly and annual gradient variability (Figure 9) do not show any significant upward or downward trend (Table 3). Such relative gradient stability is noteworthy as it could indirectly indicate that the recent climatic changes in this mountain area are not more pronounced in low than in more elevated areas. The temperature changes observed over the last 50 years would thus concern all of the French Northern Alps, with no altitudinal distinction, and would have taken place in a relatively homogeneous way at all ranges of altitude. Other authors have however suggested that the warming trends could be different depending on the elevation (e.g., Rebetez 2001 ;2006). Some studies of climate change in upland areas in other Alpine regions have shown that warming is sometimes more marked at higher altitudes (Bücher and Dessens, 1991; Weber et al., 1997). Similarly, based on data collected in Switzerland over the past 30 years, Rebetez and Reinhard, (2007) further argue that below $1100 \mathrm{~m}$, the low stations display a stronger trend than the more elevated areas, whereas above this level the warming is greater at higher than at lower elevations. Such conclusions are however always drawn from a small number of stations. In addition, they refer to models developed for very high elevations (above $4000 \mathrm{~m}$ ) in the tropical Andes (Bradley et al. 2004; 2006). These conflicting hypotheses could be directly tested for the French Northern Alps through a specific analysis of temperatures' evolution as a function of altitude.

Another factor may influence the gradient stability, specifically the time of year, as significant tendencies of monthly gradients were observed between 1960 and 2007 in November, March and April (Table 3). Indeed, in November, the minimum temperature gradient shows a trend towards a significant drop $\left(-0.013^{\circ} \mathrm{C} .100 \mathrm{~m}^{-}\right.$ $\left.{ }^{1} .10 \mathrm{yrs}^{-1}\right)$. In March and April, on the other hand, the evolution of maximum temperature gradients shows a significant rising trend $\left(+0.012\right.$ and $+0.011^{\circ} \mathrm{C} .100 \mathrm{~m}^{-}$ $\left.{ }^{1} .10 \mathrm{yrs}^{-1}\right)$.

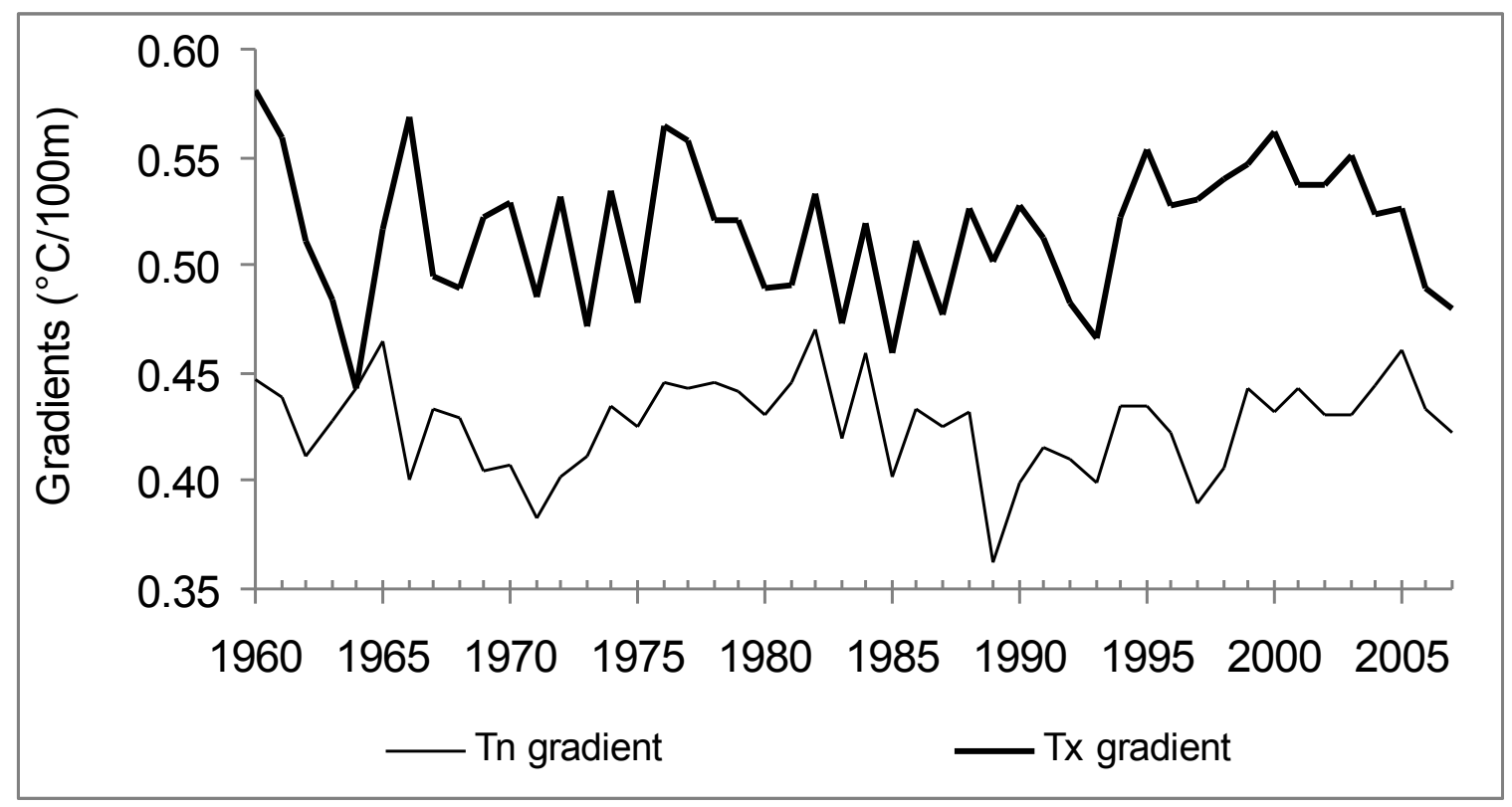

Figure 9. The evolution of annual mimimum and maximum temperature gradients in the northern Alps between 1960 and 2007 


\section{The evolution of temperatures since 1885}

Analysis of the evolution of the temperatures since 1885 is based on the reconstruction data from the monthly models for the 1885-1960 period, and on the sea level temperatures from the 92 stations for the 1960-2007 period. The evolution of annual anomalies in minimum and maximum temperatures since $1885-$ determined from the 1961-1990 climatological mean - are shown in Figures 10 and 11.

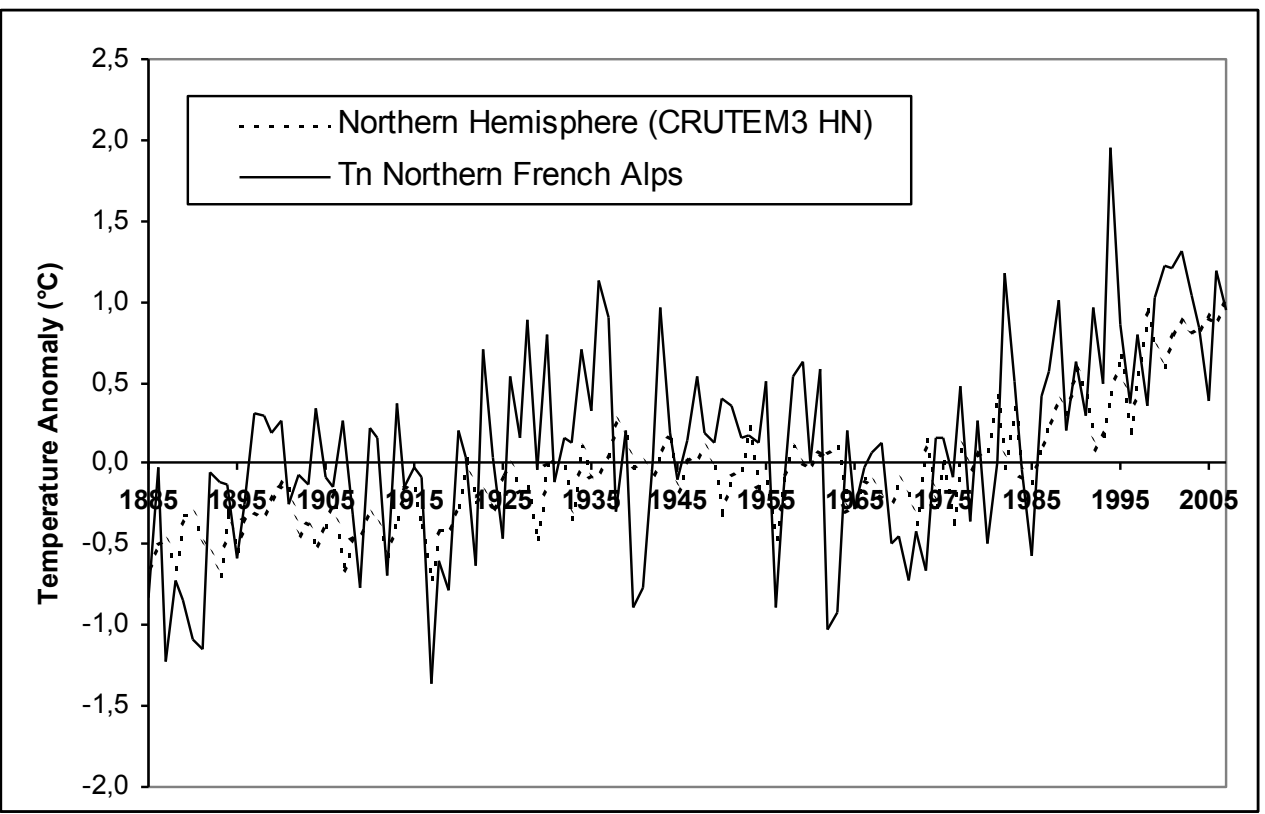

Figure 10. Minimum temperature departures from the 1961-1990 climatological mean in the French Northern Alps compared with continental Northern Hemisphere temperature anomalies (CRUTEM3 HN), for the period 1885-2007. CRUTEM3: data from the UK Meteo Hadley Centre.

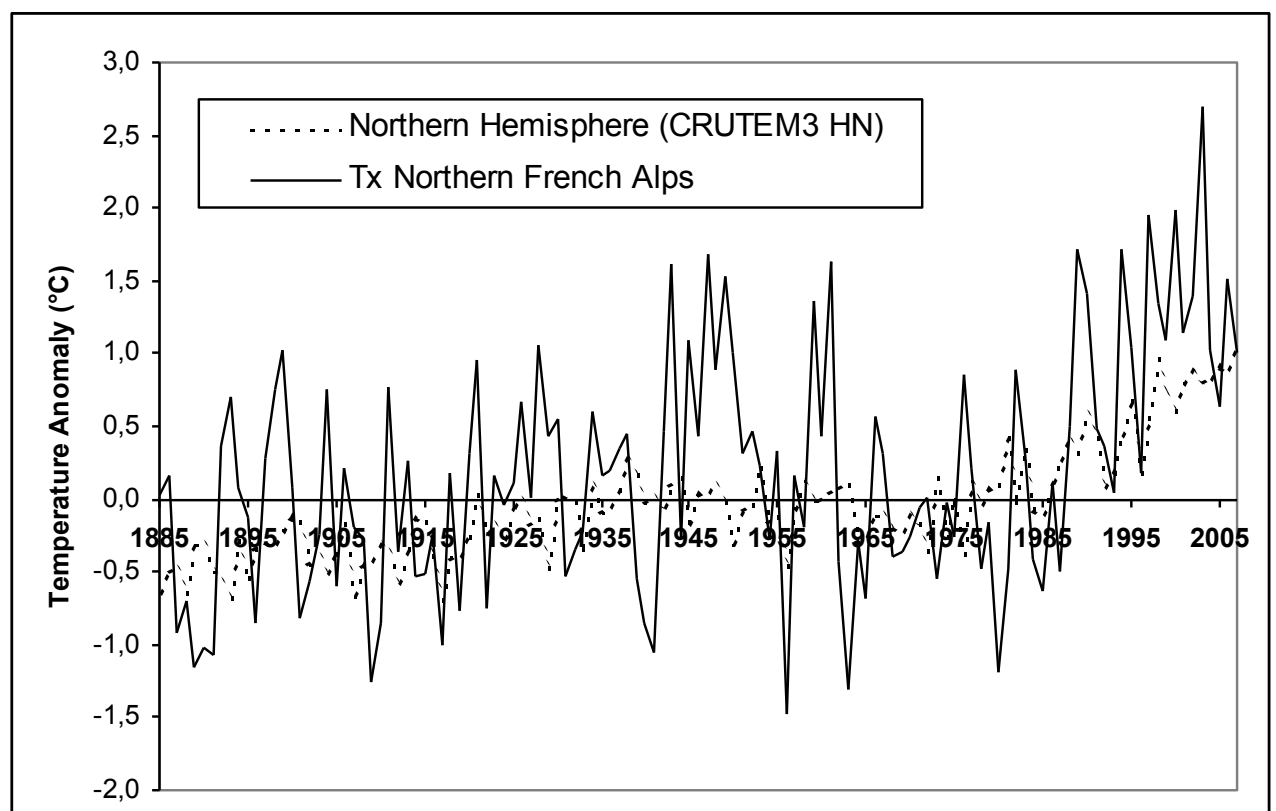

Figure 11. Maximum temperature departures from the 1961-1990 climatological mean in the French Northern Alps compared with continental Northern Hemisphere temperature anomalies (CRUTEM3 HN), for the period 1885-2007. 
The general evolution of thermal anomalies established for the French Northern Alps closely, and synchronically, follows the mean anomalies calculated for the continental Northern Hemisphere. At the hemispheric scale, temperatures fluctuate within a narrow amplitude of around $0.5^{\circ} \mathrm{C}$, whereas the amplitude is sometimes $1.5^{\circ} \mathrm{C}$ over the French Northern Alps region. In other words, the amplification of the climatic signal recorded for the continental Northern Hemisphere is five times smaller than for the Alps.

Since 1885, there has been a significant rise in annual temperatures, with a highly significant warming rate of respectively $0.87,0.84$ and $0.93^{\circ} \mathrm{C}$ per 100 years for the mean, minimum and maximum temperatures (Table 4). This figure is similar to the rate of warming observed for the whole of France over the 20th century, but had not been established so accurately for the mountain area (Moisselin et al., 2002). Between 1885 and 2007, temperature changes in the Alps were therefore close to the $0.85^{\circ} \mathrm{C}$ in 100 years observed over the whole of the Northern Hemisphere's continental regions. (CRUTEM3-NH data provided by the UK Meteo Office's Hadley Centre: Brohan et al. 2006; Jones et al., 1999; Jones and Moberg, 2003; Rayner et al., 2003, 2006). Nevertheless, the evolution of the temperatures in the Alps departs from that observed in the Northern Hemisphere starting in the 1970s. Such congruence of the temperature evolution in a mountain area with the global temperatures over the XXth century, followed by an uncoupling in the 70 s and 80 s has also been described in other mountainous regions (Weber et al., 1997; Beniston et al., 1997; Beniston, 2005; Bhutiyani et al., 2007). It has also been reported that, within a century timeframe, the rise in temperatures in mountainous areas is not always greater than that of the surrounding plains (Weber et al., 1997; Colombo et al., 2007; Rangwala and Miller, 2010).

The evolution of temperatures on a monthly scale does not appear as clear-cut. First, depending on the month, the rise does not occur with the same intensity (Figure 12). Second, for some months, a rise in temperatures cannot always be statistically validated by the Mann-Kendall test (Table 4). The results of this test suggest that neither minimum nor maximum temperatures have risen significantly in February and November. Nor can the rise be confirmed for maximum temperatures in April, June and September. Over the whole year, except for February and November, minimum temperatures show significantly greater and more regular warming than maximumu temperatures.

Table 4. Linear trend $\left({ }^{\circ} \mathrm{C}\right.$ per 100 years), 1885-2007 estimates, based on the data of the monthly models for the 1885-1960 period and on the sea level temperature from the 92 stations for the 1960-2007 period.

\begin{tabular}{|c|c|c|c|c|c|c|c|c|c|c|c|c|}
\hline & \multicolumn{3}{|c|}{ CRUTEM3 NH } & \multicolumn{3}{|c|}{$\mathrm{Tg}$} & \multicolumn{3}{|c|}{ Tn } & \multicolumn{3}{|c|}{ Tx } \\
\hline & $\begin{array}{c}\text { trend } \\
{ }^{\circ} \mathrm{C} \text { per } 100 \text { years } \\
\end{array}$ & $\mathrm{u}(\mathrm{t})$ & MK & $\begin{array}{c}\text { trend } \\
{ }^{\circ} \mathrm{C} \text { per } 100 \text { years } \\
\end{array}$ & $\mathrm{u}(\mathrm{t})$ & MK & $\begin{array}{c}\text { trend } \\
{ }^{\circ} \mathrm{C} \text { per } 100 \text { years } \\
\end{array}$ & $\mathrm{u}(\mathrm{t})$ & & $\begin{array}{c}\text { trend } \\
{ }^{\circ} \mathrm{C} \text { per } 100 \text { years } \\
\end{array}$ & $\mathrm{u}(\mathrm{t})$ & MK \\
\hline January & 1,12 & 6,53 & $* *$ & 1,52 & 2,76 & $* *$ & 1,96 & 3,39 & $* *$ & 0,90 & 1,69 & \\
\hline February & 1,32 & 7,25 & $* *$ & 0,55 & 1,03 & & 0,53 & 0,71 & & 0,53 & 0,92 & \\
\hline March & 1,27 & 8,62 & $* *$ & 0,98 & 2,45 & $*$ & 0,57 & 1,57 & & 1,45 & 2,50 & $*$ \\
\hline April & 0,93 & 8,17 & $* *$ & 0,32 & 0,84 & & 0,22 & 0,68 & & 0,78 & 1,68 & \\
\hline May & 0,76 & 8,46 & $* *$ & 0,63 & 1,58 & & 0,53 & 1,35 & & 0,82 & 1,72 & \\
\hline June & 0,66 & 7,76 & $* *$ & 0,52 & 0,79 & & 0,37 & 1,19 & & 0,54 & 0,39 & \\
\hline July & 0,53 & 6,40 & $* *$ & 1,29 & 3,15 & $* *$ & 1,41 & 4,88 & $* *$ & 1,11 & 1,99 & $*$ \\
\hline August & 0,61 & 7,38 & $* *$ & 1,26 & 3,36 & $* *$ & 1,44 & 5,32 & $* *$ & 1,08 & 2,03 & $*$ \\
\hline September & 0,52 & 6,11 & $* *$ & 0,53 & 1,45 & & 0,54 & 1,61 & & 0,54 & 1,33 & \\
\hline October & 0,68 & 6,74 & $* *$ & 1,35 & 3,02 & $* *$ & 1,05 & 2,21 & $*$ & 1,75 & 3,42 & $* *$ \\
\hline November & 0,87 & 6,48 & $* *$ & 0,24 & 0,71 & & 0,18 & 0,43 & & 0,34 & 0,89 & \\
\hline December & 0,88 & 6,08 & $* *$ & 1,21 & 2,94 & $* *$ & 1,31 & 2,89 & $* *$ & 1,26 & 2,71 & $* *$ \\
\hline Annual & 0,85 & 9,84 & $* *$ & 0,87 & 4,92 & $* *$ & 0,84 & 5,50 & $* *$ & 0,93 & 4,25 & $* *$ \\
\hline
\end{tabular}




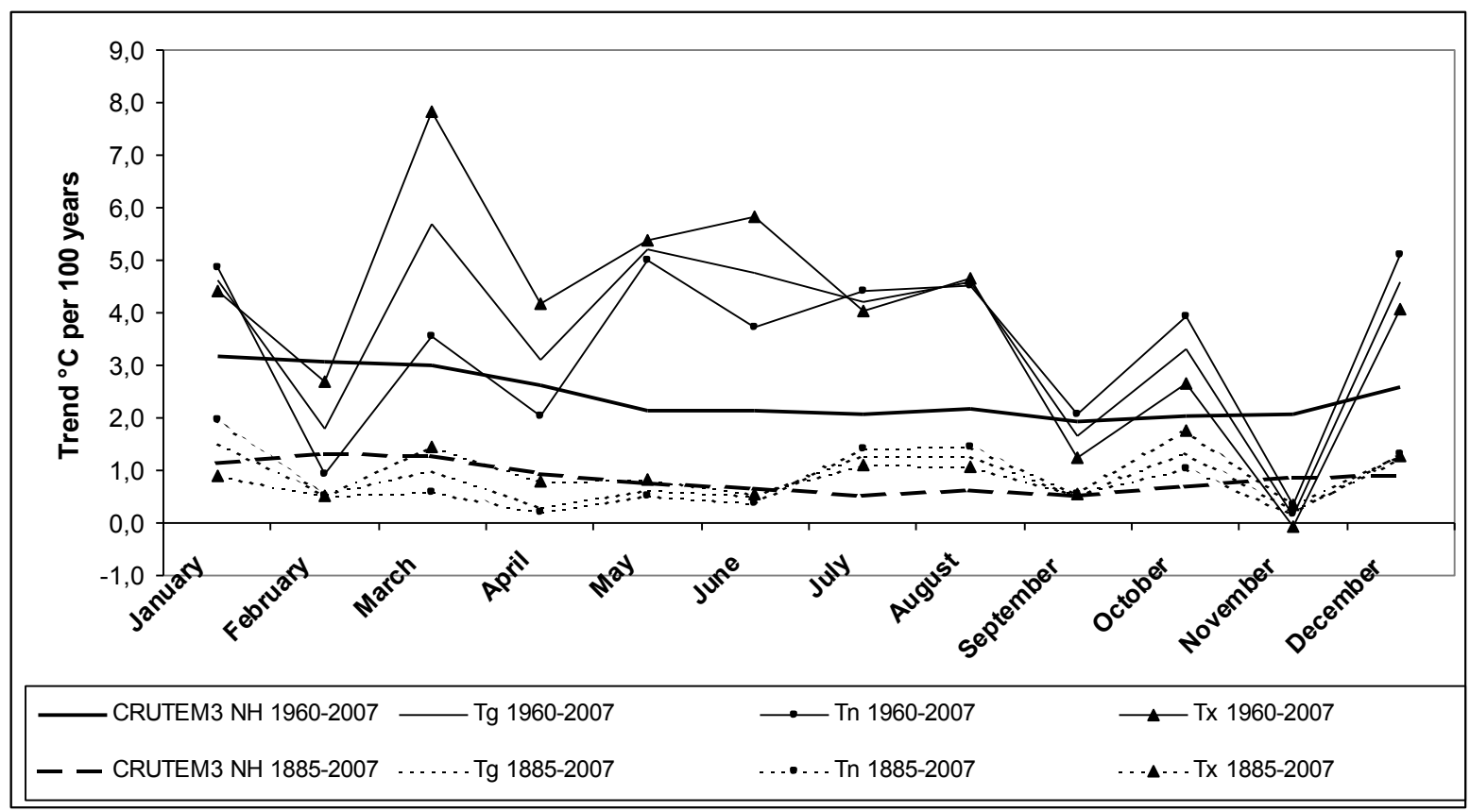

Figure 12. Yearly evolution of the monthly trends of the Tn, Tx, Tg and CRUTEM3-NH temperatures computed for 1960-2007 and 1885-2007 periods.

Important variations in monthly warming rates can also be found for the period from 1960 to 2007 (Figure 12). It appears that annual temperature means have been raising throughout the last fifty years in the French Northern Alps, and that a noticeable and highly significant increase in recorded figures has progressively taken place. The mean rise is estimated at $3.4^{\circ} \mathrm{C}$ over 100 years for minimum temperatures and $3.9^{\circ} \mathrm{C}$ over 100 years for maximum temperatures. Annual warming over the same period has been $3.6^{\circ} \mathrm{C}$, that is, two thirds greater than the rise of $2.4^{\circ} \mathrm{C}$ over 100 years observed for the whole of the Northern Hemisphere's continental areas (Table 5).

Warming has not been observed with the same rate at a monthly scale, depending on the months and specific temperature variable. Between 1960 and 2007, the highest significant monthly warming rate peaked at $7.8^{\circ} \mathrm{C}$ per 100 years for maximum temperatures in March, compared with $3.7^{\circ} \mathrm{C}$ per 100 years for the lowest significant monthly rate observed for minimum temperatures in June. Nevertheless, as for the period from 1885 to 2007 , on a monthly scale the temperatures observed over the last fifty years have not always shown indisputable warming (Table 5):

- In February and November, the warming rates of maximum and minimum temperatures cannot always be confirmed by the Mann-Kendall test. Warming rates for both these months tend moreover to be minimal, and are always smaller than those observed for the continental Northern Hemisphere.

- The rise in mean temperatures (Tg) is statistically established in March as well as from May to August and in December. For the other months of the year, although the trends may be real (e.g., in January the equivalent rise is $4.6^{\circ} \mathrm{C}$ over 100 years), they are not confirmed by MK.

- The great warming rates of monthly minimum temperatures (Tn), always 
above $3.7^{\circ} \mathrm{C}$ per 100 years, are statistically significant in only seven months out of 12: in December and January, from May to August, and in October.

- Finally, for maximum temperatures monthly warming rates, even though sometimes very strong, are significant for only four months of the year: March, May, June, and August. It cannot not be statistically demonstrated that the other months' maximum temperatures have risen since 1960 .

Table 5. Linear trend $\left({ }^{\circ} \mathrm{C}\right.$ per 100 years), $1960-2007$ calculated based on the sea level temperatures obtained from the 92 stations.

\begin{tabular}{|c|c|c|c|c|c|c|c|c|c|c|c|c|}
\hline & $\begin{array}{c}\text { CRUTEN } \\
\text { trend } \\
{ }^{\circ} \mathrm{C} \text { per } 100 \text { years }\end{array}$ & $\begin{array}{l}\text { NH } \\
u(t)\end{array}$ & MK & 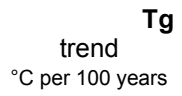 & $\mathrm{u}(\mathrm{t})$ & MK & $\begin{array}{c}\text { Tn } \\
\text { trend } \\
{ }^{\circ} \mathrm{C} \text { per } 100 \text { years }\end{array}$ & $\mathrm{u}(\mathrm{t})$ & & $\begin{array}{l}\text { trend } \\
{ }^{\circ} \mathrm{C} \text { per } 100 \text { years }\end{array}$ & $\mathrm{u}(\mathrm{t})$ & MK \\
\hline January & 3.18 & 5.14 & $* *$ & 4.64 & 1.96 & & 4.86 & 2.28 & $*$ & 4.41 & 1.72 & \\
\hline February & 3.08 & 4.21 & $* *$ & 1.80 & 0.66 & & 0.92 & 0.02 & & 2.67 & 0.75 & \\
\hline March & 2.98 & 5.35 & $* *$ & 5.68 & 2.92 & $* *$ & 3.54 & 1.81 & & 7.81 & 3.06 & $* *$ \\
\hline April & 2.64 & 6.13 & $* *$ & 3.09 & 1.92 & & 2.02 & 1.69 & & 4.17 & 1.83 & \\
\hline May & 2.14 & 6.81 & $* *$ & 5.20 & 3.02 & $* *$ & 5.01 & 3.59 & $* *$ & 5.39 & 2.42 & $*$ \\
\hline June & 2.13 & 6.22 & $* *$ & 4.77 & 2.99 & $* *$ & 3.73 & 3.20 & $* *$ & 5.82 & 2.52 & $*$ \\
\hline July & 2.05 & 5.94 & $* *$ & 4.22 & 2.56 & $*$ & 4.40 & 3.34 & $* *$ & 4.04 & 1.78 & \\
\hline August & 2.17 & 5.94 & $* *$ & 4.59 & 2.97 & $* *$ & 4.52 & 4.05 & $* *$ & 4.66 & 2.15 & $*$ \\
\hline September & 1.94 & 5.48 & $* *$ & 1.65 & 1.35 & & 2.06 & 1.71 & & 1.23 & 0.84 & \\
\hline October & 2.05 & 5.12 & $* *$ & 3.30 & 1.94 & & 3.93 & 2.47 & $*$ & 2.66 & 1.37 & \\
\hline November & 2.05 & 4.09 & $* *$ & 0.15 & 0.12 & & 0.36 & -0.05 & & -0.05 & 0.07 & \\
\hline December & 2.58 & 5.23 & $* *$ & 4.58 & 2.31 & $*$ & 5.09 & 2.51 & $*$ & 4.07 & 1.78 & \\
\hline Annual & 2.42 & 6.54 & $* *$ & 3.64 & 5.05 & $* *$ & 3.37 & 5.33 & $* *$ & 3.91 & 4.21 & $* *$ \\
\hline
\end{tabular}

\section{CONCLUSION}

The evolutions of regional temperatures and gradients in the French Northern Alps greatly vary depending on the month of the year, the specific temperature measure (Tn, $\mathrm{Tx}$, or $\mathrm{Tg})$, as well as the period of time investigated.

The inter-annual evolution of gradients over the last fifty years is undoubtedly the trickiest to evaluate. Annual and monthly gradients show large inter-annual variations, and apart from minimum temperatures in November, and maximum temperatures in March-April, there seems to have been no significant evolution since 1960. The stability of the gradients over the last fifty years could thus indirectly reflect the fact that temperature changes in the French Northern Alps affect the entire area in a relatively uniform way, a hypothesis that contrasts with conclusions drawn from smaller scale observations made in other Alpine areas. However, the seasonal variations of these gradients are easier to interpret. Shallow winter gradients and steeper summer ones reflect, among other factors, the influence of thermal inversions on the minima. This is not a novel observation regarding mountain area, but is nevertheless the first time that temperature gradients are precisely assessed for the French Northern Alps.

Between 1885 and 2007, and since 1960, temperature changes in the French NorthernAlps have been more conspicuous at an annual scale. For the 1885-2007 period, the Alpine range sustained the global modifications due to climate change at an annual scale without much amplification. The same cannot however be said for the period starting in 1960, where observed warming rates have clearly increased. Over the last few decades, this 
amplification has become even more noticeable at a monthly scale, with warming rates often exceeding $4.0^{\circ} \mathrm{C}$ per 100 years. This is to be compared to a mean monthly warming rate of $2.4^{\circ} \mathrm{C}$ per 100 years for the Northern Hemisphere's continental regions. The increase in monthly temperatures is nevertheless much more variable depending on the month. In addition, whatever the time period studied, all monthly temperatures do not always indicate significant, indisputable warming.

\section{REFERENCES}

Angot, A. 1892. Sur la de'croissance de la température de l'air avec la hauteur. C. R. Acad. Sci., 115, 1272-1273.

Barry, R.G. and R.J. Chorley, 1998. Atmosphere, weather and climate. 7ème edition Routledge.

Barry, R. G., 2008. Mountain weather and climate. Routledge Physical and Environmental Series. 3nd ed. Routledge, London and New York.

Beniston, M., M. Rebetez, F. Giorgi and M. Marinucci, 1994. An analysis of regional climate change in Switzerland. Theor. Appl. Clim. 49: 135-159.

Beniston M., Diaz H.F., Bradley R.S., 1997. Climatic change at high elevation sites: an overview. Climatic Change, 36, 233-251.

Beniston M., 2005. Mountain Climates and Climatic Change: An Overview of Processes Focusing on the European Alps. Pure and Applied Geophysics, volume 162, Numbers 8-9, 1587-1606.

Beniston M., 2006. Mountain weather and climate: a general overview and a focus on climatic change in the Alps. Hydrobiologia, 562, 3-16.

Bhutiyani, M.R., Kale, S.V., Pawa N.J., 2007. Long-term trends in maximum, minimum and mean annual air temperatures across the Northwestern
Himalaya during the twentieth century. Climatic Change, volume: 85, Issue: 1-2, 159-177.

Bisci, C., Cellini, M., Farabollini, P. and C. Pittori, 1989. Le gradient thermique dans les Marches méridionales (Italie Centrale). Proc. Actes du Colloque de Pavia, Italy, Vol. 2, Association Internationale de Climatologie, 27-33.

Böhm, R., Auer I., Brunetti M., Maugeri M., Nanni T and Schöner W., 2001. Regional temperature variability in the European Alps 1760-1998 from homogenised instrumental time series. International Journal of Climatology, 21, 1779-1801.

Bois P., 1971. Une méthode de contrôle de séries chronologiques utilisées en climatologie et en hydrologie. Publication du Laboratoire de Mécanique des Fluides. Section hydrologie. Univ. de Grenoble.

Bradley R.S., Keimig F.T., Diaz H.F., 2004. Projected temperature changes along the American cordillera and the planned GCOS network. Geophys Res Lett 31: L16210.

Bradley R.S., Vuille M., Diaz H.F., Vergara W., 2006. Threats to water supplies in the tropical Andes. Science 312: 1755-1756.

Brohan, P., J.J. Kennedy, I. Harris, S.F.B. Tett and P.D. Jones, 2006: Uncertainty estimates in regional and global observed temperature changes: a new dataset from 1850. J. Geophysical Research Letters , 31, 1029-1032.

Bücher, A. and J. Dessens, 1991. Secular trend of surface temperature at an elevated observatory in the Pyrenees. J. Clim. 4: 859-868.

Buishand T.A., 1984. Tests for detecting a shift in the mean of hydrological time series. Journal of Hydrology, vol. 58, 5169.

Casty C., Wanner H., Luterbacher J., Esper J. and Böhm R., 2005. Temperature and 
precipitation variability in the European Alps since 1500. Int. Jo. of Climatology, 25: $1855-1880$.

Caussinus H, Mestre O. 2004. Detection and correction of artificial shifts in climate series. Journal of the Royal Statistical Society: Series C (Applied Statistics) 53: 405-425.

Colombo T., Pelino V., Vergari S., Cristofanelli P., Bonasoni P., 2007. Study of temperature and precipitation variations in Italy based on surface instrumental observations. Global and Planetary Change 57, 308-318.

Diaz, H. and R. Bradley, 1997. Temperature variations during the last century at high elevation sites. Clim. Change 36: 253-279.

Douguédroit A. and Saintignon (de) M.-F., 1981. Décroissance des températures mensuelles et annuelles avec l'altitude dans les Alpes du Sud et en Provence (séries 1959-1978). Eaux et Climat: mélanges géographiques offerts en hommage a ' Charles-Pierre Péguy, ER 30, 179-194.

Douguédroit A. and Saintignon (de) M.-F., 1984. Les gradients de températures et de précipitations en montagne. Rev. de Géogr. Alpine, LXXII, 225-240.

Dumas D. and Antunes C., 2003. Evolution des températures minimales dans les Alpes du Nord depuis 1960. Association Internationale de Climatologie, vol. 15, 413-420.

Dumas D. and Rome S., 2009. Les températures dans les Alpes du Nord: influence de l'altitude et évolution depuis 1960. Geographia Technica, numéro spécial, XXIIème colloque de l'Association Internationale de Climatologie, 395-400.

Easterling D.R., Horton B., Jones Ph.D., Peterson T.C., Karl T.R., Parker D.E., Salinger M.J., Razuvayev V., Plummer N., Jamason P., Folland C.K., 1997. Maximum and Minimum Temperature Trends for the Globe. Science, volume 277(5324), 364367.

Gerstengarbe F.W., Werner P.C., 1999. Estimation of the beginning and end of recurrent events within a climate regime. Climate Research, vol. 11, 97-107.

Harding R.J., 1978. The variation of the altitudinal gradient of temperature within the British Isles. Geografiska Annaler, 60 A, 1-2, 43-49.

Harris C., Von der Mühll D., Isaksen K., Haeberli W., Sollid J.L., King L., P. Holmlund, F. Dramis, M. Guglielmin and D. Palacios, 2003. Warming permafrost in European mountains. Global and Planetary Change 39: 215-225.

Hirsch, R. M. and Slack, J. R.: 1984. Nonparametric trend test for seasonal data with serial dependence, Water Resour. Res. 20(6), 727-732.

Hubert P., Carbonnel J.P., Chaouche A., 1989. Segmentation des séries hydrométéorologiques. Application à des séries de précipitations et de débits de l'Afrique de l'Ouest. Journal of Hydrology, vol. 110, 349-367.

Jones, P.D., New, M., Parker, D.E., Martin, S. and Rigor, I.G., 1999. Surface air temperature and its variations over the last 150 years. Reviews of Geophysics 37, 173-199.

Jones P.D., Moberg A., 2003. Hemispheric and large-scale surface air temperature variations: An extensive revision and an update to 2001. Journal of Climate 16: 206-223.

Kendall, M. G.: 1975, Rank Correlation Methods, Griffin, London.

Kundzewicz, Z. W., Robson A., 2000. Detecting trends and other changes in hydrological data. World Climate Programme-Water, WCDMP-45, WMO/TD-No. 1013, OMM, Geneva. 
Kundzewicz, Z.W., Graczyk D., Maurer T., Przymusińska I., Radziejewski M., Svensson C. et Szwed M., 2005. Trend detection in river flow time-series: 1. annual maximum flow. Hydrol. Sci. J., 50(5), 797-810.

Ladiray D., Quenneville B., 2001. Seasonal adjustment with the $\mathrm{X}-11$ Method. Springer-Verlag, Statistics ${ }^{\circ} 158$.

Mann, H. B.: 1945. Nonparametric tests against trend. Econometrica 13, 245-259.

Mestre O., 2000. Méthodes statistiques pour l'homogénéisation de longues séries climatiques. Thése de Mathématiques appliquées et Statistiques. Univ. Paul Sabatier, Toulouse.

Moisselin J.M., Schneider M., Canellas C., Mestre O., 2002. Les changements climatiques en France au XXe siècle. La Météorologie, 8ème série, n³8, 45-56.

Rangwala I. and Miller J.R., 2010. Twentieth Century Temperature Trends in Colorado's San Juan Mountains. Arctic, Antarctic, and Alpine Research 42(1): 8997.

Rayner, N.A., Parker, D.E., Horton, E.B., Folland, C.K., Alexander, L.V, Rowell, D.P., Kent, E.C. and Kaplan, A., 2003: Globally complete analyses of sea surface temperature, sea ice and night marine air temperature, 1871-2000. J. Geophysical Research 108, 4407.

Rayner, N.A., P. Brohan, D.E. Parker, C.K. Folland, J.J. Kennedy, M. Vanicek, T. Ansell and S.F.B. Tett, 2006: Improved analyses of changes and uncertainties in marine temperature measured in situ since the mid-nineteenth century: the HadSST2 dataset. J. Climate, 19, 446-469.

Rebetez M., 2001. Changes in daily and nightly day-to-day temperature variability during the twentieth century for two stations in Switzerland. Theor. Appl. Clim, 69: 13-21.

Rebetez M., 2006. La Suisse se réchauffe ; effet de serre et changement climatique.
Presses polytechniques et universitaire romandes, collection « Le savoir suisse », $144 \mathrm{p}$.

Rebetez M., Reinhard M., 2008. Monthly air temperature trends in Switzerland 1901-2000 and 1975-2004. Theor. Appl. Climatol. 91: 27-34.

Rolland C., 2003. Spatial and Seasonal Variations of Air Temperature Lapse Rates in Alpine Regions. J. Climate, 16, 10321046.

Saintignon (de) M.-F., 1976. Décroissance des températures en montagne de latitude moyenne: exemple des Alpes françaises du Nord. Rev. de Géo. Alpine, LXIV, 4, 483494.

Sneyers R., 1975. Sur l'analyse statistique des séries d'observations. Note technique $\mathrm{n}^{\circ} 143$ de l'Organisation Météorologique Mondiale, Geneva.

Triplet P., Roche G., 2000. Météorologie générale, École nationale de la météorologie, France.

Vialar J., 1978. Calcul des probabilités et statistiques. Secrétariat d'Etat auprès du Ministre de l'équipement, Direction de la Météorologie, Tome IV Statistique: étude des séries chronologiques, Paris.

Weber, R., P. Talkner, I. Auer, R. Böhm, M. Gajic-Capka, K. Zaninovic, R. Brádzil \& P. Faško, 1997. 20th-century changes of temperature in the mountain regions of central Europe. Clim. Change 36: 327344.

Yue S., Pilon P., Cavadias G., 2002. Power of Mann-Kendall and Spearman's ro tests for detecting monotonic trends in hydrological series. Journal of Hydrology, 259, 254-271. 